\title{
A Terrestrial Microbial Fuel Cell for Powering a Single-Hop Wireless Sensor Network
}

\author{
Daxing Zhang ${ }^{1, *}$, Yingmin Zhu ${ }^{1}$, Witold Pedrycz ${ }^{1,2,3}$ and Yongxian Guo ${ }^{4}$ \\ 1 School of Mechano-Electronic Engineering, Xidian University, Xi'an 710071, China; \\ ymzhu@xidian.edu.cn (Y.Z.); wpedrycz@ualberta.ca (W.P.) \\ 2 Department of Electrical and Computer Engineering, University of Alberta, Edmonton, AB T6G 2R3, Canada \\ 3 Department of Electrical and Computer Engineering, Faculty of Engineering, King Abdulaziz University, \\ Jeddah 21589, Saudi Arabia \\ 4 Institute of Engineering Thermophysics, Chinese Academy of Sciences, Beijing 100190, China; \\ guoyongxian@iet.cn \\ * Correspondence: zhangdx@xidian.edu.cn; Tel.: +86-29-8820-3115 \\ Academic Editor: Deepak Pant \\ Received: 23 March 2016; Accepted: 10 May 2016; Published: 18 May 2016
}

\begin{abstract}
Microbial fuel cells (MFCs) are envisioned as one of the most promising alternative renewable energy sources because they can generate electric current continuously while treating waste. Terrestrial Microbial Fuel Cells (TMFCs) can be inoculated and work on the use of soil, which further extends the application areas of MFCs. Energy supply, as a primary influential factor determining the lifetime of Wireless Sensor Network (WSN) nodes, remains an open challenge in sensor networks. In theory, sensor nodes powered by MFCs have an eternal life. However, low power density and high internal resistance of MFCs are two pronounced problems in their operation. A single-hop WSN powered by a TMFC experimental setup was designed and experimented with. Power generation performance of the proposed TMFC, the relationships between the performance of the power generation and the environment temperature, the water content of the soil by weight were measured by experiments. Results show that the TMFC can achieve good power generation performance under special environmental conditions. Furthermore, the experiments with sensor data acquisition and wireless transmission of the TMFC powering WSN were carried out. We demonstrate that the obtained experimental results validate the feasibility of TMFCs powering WSNs.
\end{abstract}

Keywords: terrestrial microbial fuel cell; wireless sensor network; energy harvesting; power management

\section{Introduction}

Microbial fuel cells (MFCs), converting chemical energy from organic compounds to electrical energy through catalytic reactions of microorganisms, can be envisioned as archetypical microbial Bioelectrochemical Systems (BESs). MFCs have attracted a large amount of interest in the past decade because they can generate electric power while treating waste. Unlike other fuel cells, MFCs can continuously generate power at normal temperature, atmospheric pressure, and neutral $\mathrm{pH}$ value without any additional maintenance. In addition, the only byproducts are $\mathrm{CO}_{2}$ and $\mathrm{H}_{2} \mathrm{O}$, which do not require additional handling. Thus, MFCs have been widely considered as one of the devices harvesting sustainable energy [1-5]. In America, it causes about $1.5 \%$ of the municipal energy consumption for waste water treatment. In some industrialized countries, the wastewater treatment results in about $10 \%$ of the municipal energy consumption [1]. At the same time, the energy content of municipal wastewater is considered to be nine times higher than the energy demand necessary for its treatment [6]. 
There is an enormous potentiality and great prospects for development to generate electric power through treating wastewater.

Research exploiting the bioelectrocatalytic activity of living microorganisms to generate electric power have a history of 100 years [7]; however, MFCs as a novel technology is still in development. Systematic MFC development started only a decade ago [8]. At present, the aquatic microbial fuel cells (AMFCs) power generation properties have been verified, and many efforts were made to improve the power generation properties and the energy harvesting efficiency [1,4,9-20]. AMFCs are validated for powering small electronic devices [21-33]. However, AMFCs must be inoculated and work in the water environment [1-5], which limits the MFCs' application fields. Terrestrial microbial fuel cells (TMFCs) can be inoculated and worked on land [34-36], which can overcome the disadvantages of AMFCs and extend the MFCs' application range.

The concept of TMFC was first presented in 2010. A TMFC setup was designed to power a wireless environmental sensor network. Unfortunately, it was found that more than two-thirds of sensor nodes worked improperly. More importantly, no certain conclusion about the nature of this problem was formulated [34]. In successive years, little progress has been made in the study of TMFCs [35,36]. TMFCs cannot be widely adopted because of several pronounced challenges. Among them, the low power density and low reliability are two open problems [34-36]. As a result, a Power Management System (PMS) is usually required to connect a TMFC to the load. Low efficiency is one of the main problems in the PMS development. Much effort has been made to develop an appropriate PMS $[11,16,19,25,28,29,33]$. So far, no universal PMS has been proposed. Some environmental factors affect the power density of TMFC, among them including temperature, soil bacteria, and biological content [34-36]. However, at present, the relationships between the power generation performance and environmental factors are still under discussion. Further research should be completed to arrive at sound conclusions.

Wireless sensor networks (WSNs), as the first of ten new technologies deeply affecting human future life, exhibit a tremendous value for a broad range of applications. They play an increasingly important role in military, industrial, and consumer applications [23,37-40]. However, the long-lasting power supply for WSN nodes remains one of the bottlenecks hampering their further rapid development. Power sources are one of the most important and influential factors determining the lifetime of WSN nodes, especially for remote environment monitoring applications. Reducing power consumption, improving the efficiency of power consumption, and developing new power supply methods are effective ways to solve this problem. WSN nodes powered by energy harvesting sources could theoretically have an eternal lifespan [38-40].

The findings in this regard are the ultimate subject of this study. In this study, our aim is to improve the performance of the proposed TMFC and develop a TMFC powering of a single-hop WSN node experimental setup. The intent is to come up with a new reliable method for powering the WSN node for a long time.

\section{Results}

\subsection{Terrestrial Microbial Fuel Cell (TMFC) Performance}

The performances of the proposed TMFC including the voltage between electrodes during inoculation, the open circuit voltage $(\mathrm{OCV})$, and the polarization curve were reported through a series of experiments.

\subsubsection{Voltage between Electrodes in the Inoculation Experiment}

The voltage between electrodes in the inoculation experiment is shown in Figure 1. After injecting the medium, the voltage between the electrodes starts increasing. About $30 \mathrm{~h}$ later, a rapid voltage (current) increase is found. This phenomenon is also observed in our AMFC experiments, and it has 
also been verified in other papers $[1,4,25]$. About $80 \mathrm{~h}$ later, the voltage stabilizes at a value of about $0.3 \mathrm{~V}$.

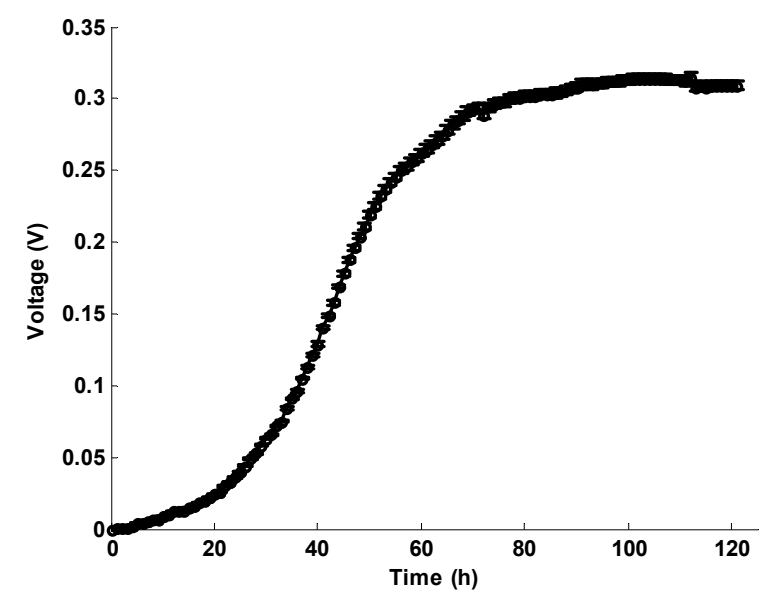

Figure 1. Voltage between electrodes in the inoculation experiment.

\subsubsection{Open Circuit Voltage}

After the inoculation experiment, the resistor between electrodes was disconnected, and the OCV was tested; refer to Figure 2. It took about $25 \mathrm{~h}$ for the voltage between electrodes to become stable. The experiment can be implemented any time after inoculation. The OCV of the proposed TMFC is about $0.75 \mathrm{~V}$, which is a reasonable value for MFCs [1].

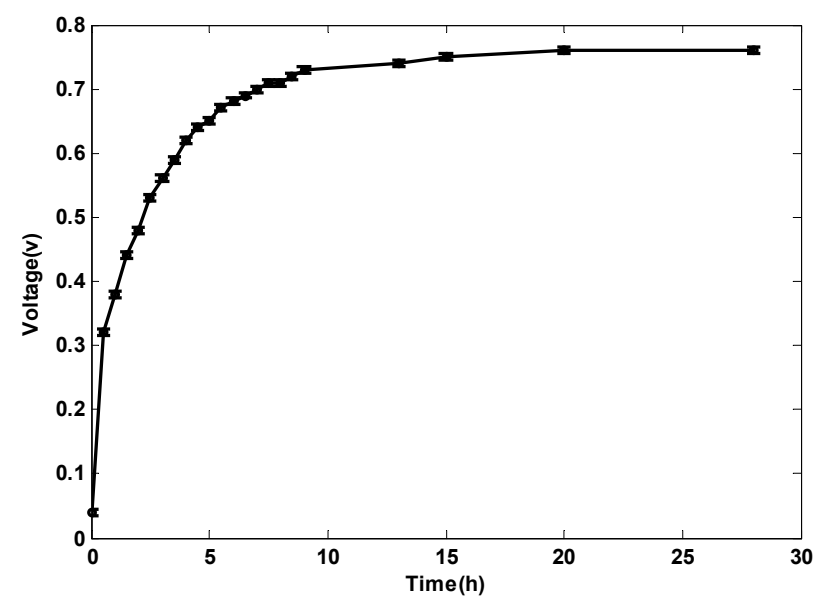

Figure 2. Open circuit voltage (OCV) of the proposed terrestrial microbial fuel cell (TMFC).

\subsubsection{Polarization and Power Curves}

Polarization and power curves are the representative characteristics for the power generation performance of MFCs. These curves of the proposed TMFC (Figure 3) were obtained according to the procedure detailed in Materials and Methods.

The proposed TMFC has an OCV of about $0.75 \mathrm{~V}$, and the maximum current density is about $20 \mathrm{~mA} / \mathrm{m}^{2}$, which are reasonable values for typical MFCs [1]. The TMFC exhibited a maximum power density of roughly $3 \mathrm{~mW} / \mathrm{m}^{2}$ of anode surface area, which is lower than the maximum power density of the AMFC established in our previous study [19]. No membrane is used in this study, which may lead to a low efficiency of the setup. Additionally, the activity of microorganisms in water is usually higher than in soil. These may be the reasons for the lower power density of the proposed TMFC. The lower power density leads to a longer duty cycle of the PMS and the WSN platform, which is not 
the key problem for a long-term monitoring application of WSNs. The advantages of our TMFC are the simple architecture and economical materials.

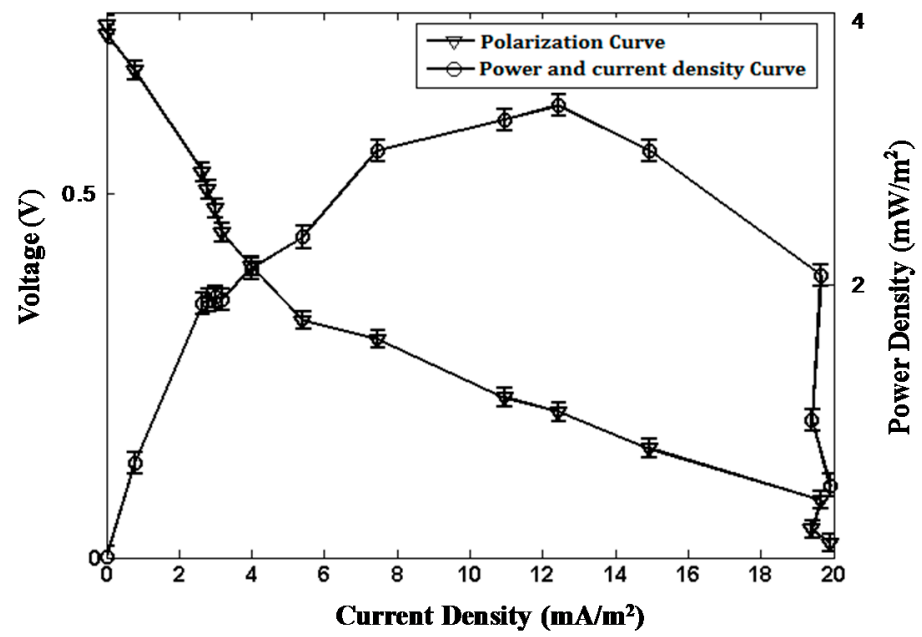

Figure 3. Polarization and power curves of the TMFC.

\subsection{Relationship between the Proposed TMFC Properties and Environmental Factors}

\subsubsection{Soil Moisture Content}

The relationship between the soil moisture content by weight and the output power density of the TMFC is recorded; refer to Figure 4 . The output power density nears zero when the soil moisture content is below approximately $0.2 \mathrm{~g} / \mathrm{g}$. The power density increases with the increase of soil moisture content, while the soil water content is between 0.2 and $0.4 \mathrm{~g} / \mathrm{g}$. The output power density achieves the maximum when the soil moisture content approaches $0.4 \mathrm{~g} / \mathrm{g}$. The power density remains unchanged if the soil moisture content exceeds $0.4 \mathrm{~g} / \mathrm{g}$.

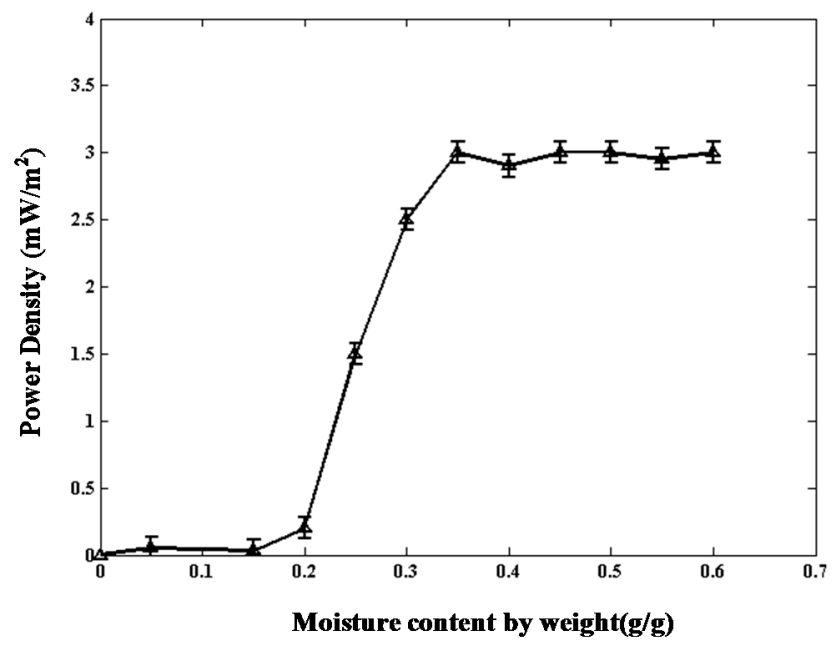

Figure 4. Relationship between the soil moisture content and the power density.

\subsubsection{Temperature}

We recorded the relationship between temperature and the power density of the proposed TMFC. The result is shown in Figure 5. As shown in the figure, the output power density increases with the increase of temperature, while the temperature is below $36^{\circ} \mathrm{C}$. The output density begins to drop when the temperature is greater than $36^{\circ} \mathrm{C}$. 


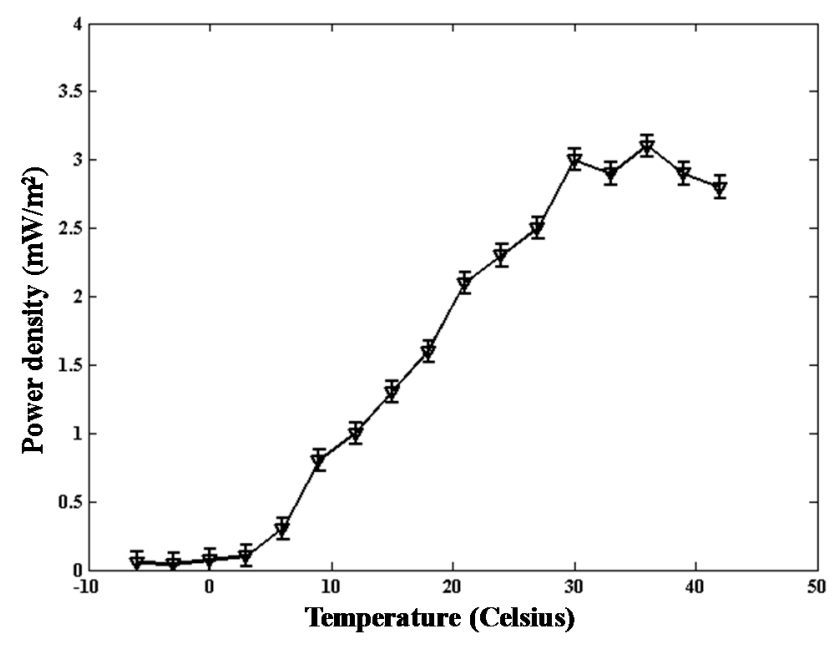

Figure 5. Relationship between the power density and temperature.

It is not convenient to maintain a specific temperature while running experiments. Noticeably, the output power density exhibits little difference between room temperature (about $25^{\circ} \mathrm{C}$ ) and $36{ }^{\circ} \mathrm{C}$. Subsequently, other experiments were realized at room temperature, and the soil water content by weight is kept at about $0.4 \mathrm{~g} / \mathrm{g}$.

\subsection{Voltages on Super-Capacitors in the Power Management System (PMS) Board}

In order to characterize the performance of the PMS, we recorded the voltages on the super-capacitors in the PMS board (Figure 6).

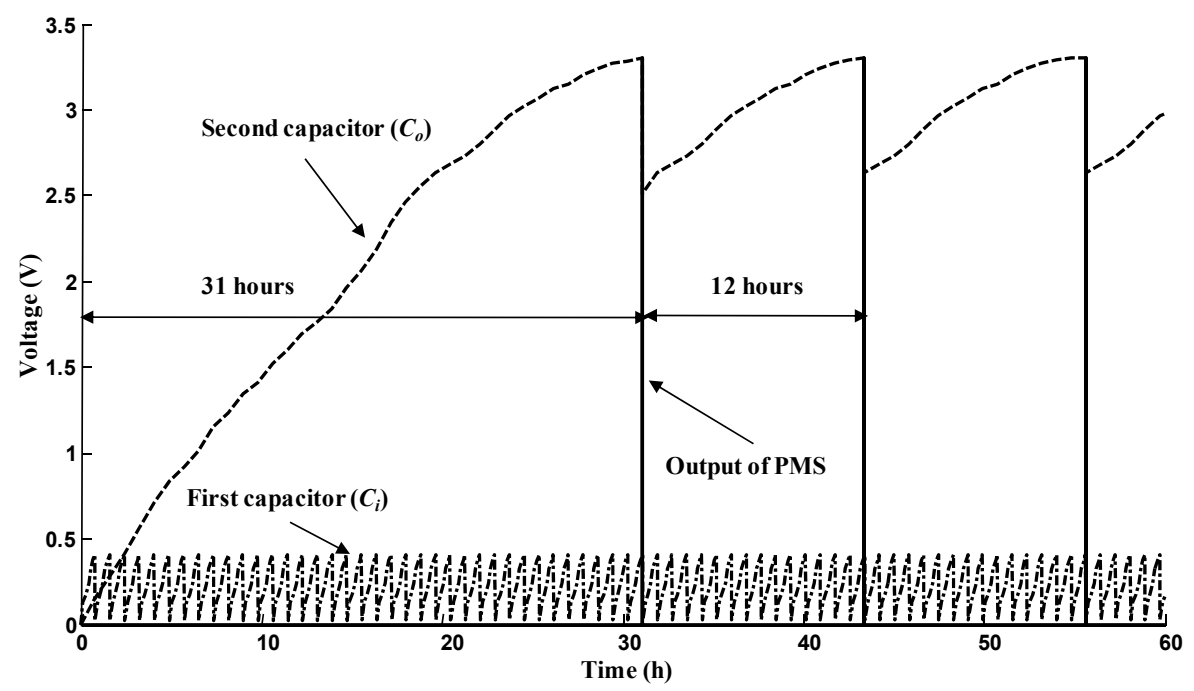

Figure 6. Voltage recorded on super-capacitors of the Power Management System (PMS) board.

The PMS board works as in the literature [19]. The charge-discharge cycle of the first super-capacitor is about $0.85 \mathrm{~h}( \pm 0.05)$. The stable duty cycle is about $12 \mathrm{~h}( \pm 0.5)$.

\subsection{Wireless Sensor Network (WSN) Application}

The sensor node experimental devices are shown in Figure 7. The signal processing board and controller and radio board are powered by the TMFC through the PMS board. The voltage of TMFC output (the voltage on the first super-capacitor) and the voltage of PMS output (the voltage on the second super-capacitor) are monitored by multimeters. 


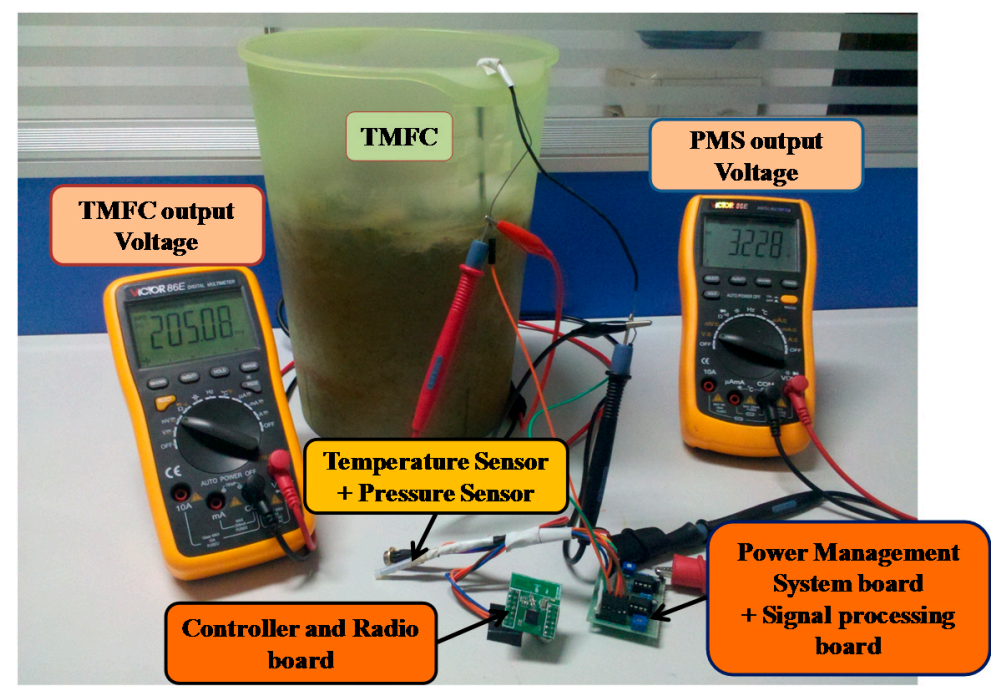

Figure 7. Photo of the experimental setup of the sensor node.

The maximum output voltage of the PMS board is $3.3 \mathrm{~V}$, which meets the working voltage requirement of the WSN board. However, the WSN board can transmit data only when the second super-capacitor (Co) stores enough energy, which depends on the value of the second super-capacitor (Co). As mentioned above, its capacitance is $100 \mathrm{mF}$ (the choice of this value is based on experimental results [19]). The sensor node, powered by the TMFC, acquires and transmits data to the access point periodically. The sensor data that are received by the access point are transmitted to the PC via the RS232 interface. The sensor data saved on the PC are shown in Figure 8.

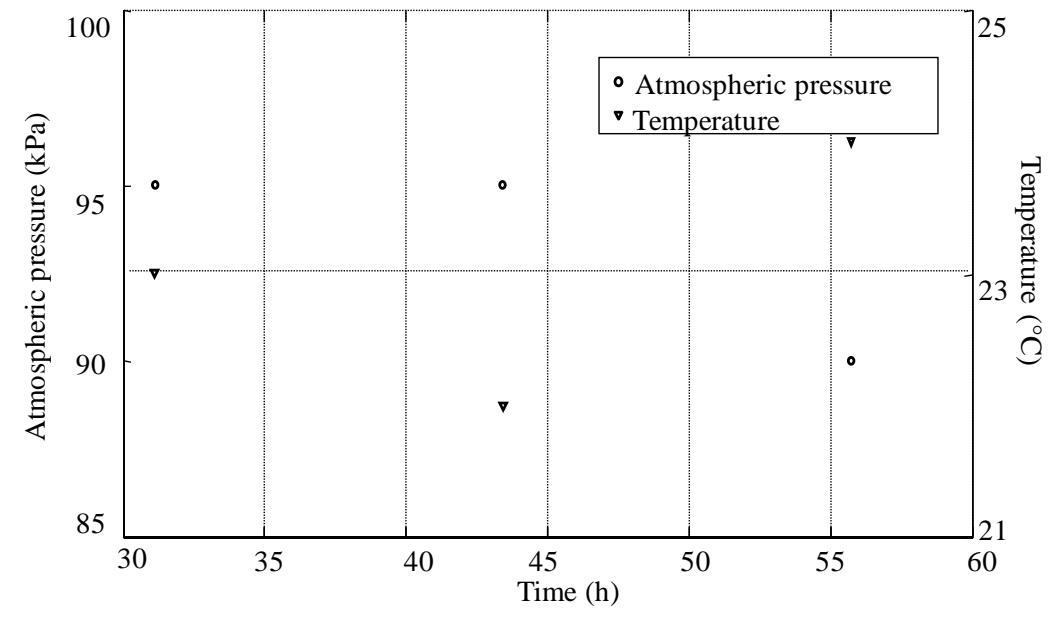

Figure 8. Sensor data received by access point.

The access point receives three packets each period, which includes the temperature and atmospheric pressure information. The stable duty cycle is about $12 \mathrm{~h}$, which is in accordance with the duty cycle of the PMS board. Because the experiments were implemented in the laboratory environment, the sensor data do not vary too much over time.

\section{Discussion}

Experimental results show that the WSN board works properly by being powered by the proposed TMFC reactor. Due to the low output voltage and low output power coming from the TMFC, the output voltage must be boosted, and the energy must be accumulated through the PMS board before 
powering the WSN board. Therefore, the WSN board can only work periodically. The duty cycle depends on the performance of the TMFC, the value of the super-capacitors on the PMS board, and the power consumption of the load. The environment temperature and the soil moisture content by weight are critical to the improvement of the performance of the TMFC.

It would be interesting to use TMFCs to power electronic devices for longer times and with shorter duty cycles. Improving the power generation properties of the TMFCs and/or developing a more efficient PMS could be effective methods. Future studies may include as follows: the determination of other influence factors, such as soil bacteria and biological content for TMFC power generation properties; and the development of WSN protocols while using the proposed TMFC.

\section{Materials and Methods}

\subsection{Terrestrial Microbial Fuel Cell Device}

A TMFC experimental device has been designed and constructed; see Figure 9. The TMFC reactor is a plastic bucket. The diameter is $150 \mathrm{~mm}$ at the bottom, and $190 \mathrm{~mm}$ at the top. It has a height of $260 \mathrm{~mm}$. The anode material is carbon cloth (HCP330, Hesen, Shanghai, China), which is a disk of $160 \mathrm{~mm}$ diameter, and it is placed at a height of $45 \mathrm{~mm}$ from the bottom of the bucket. The cathode material is carbon paper (HCP030, Hesen, Shanghai, China), which is a disk that is $160 \mathrm{~mm}$ in diameter. The anode is covered with Pt-catalyst (XC-72, Fuel Cell Store, Boulder, CO, USA). The electrodes have a distance of $110 \mathrm{~mm}$. On the top of the cathode, a layer of rocks is placed. This provides the deformation of the carbon paper. The electronic loads were connected to the anode and cathode by two titanium wires. We collected soil from the forest (Qinling Mountains, Xi'an, China) off the beaten path, which tends to be rich of microbes and nutriments.
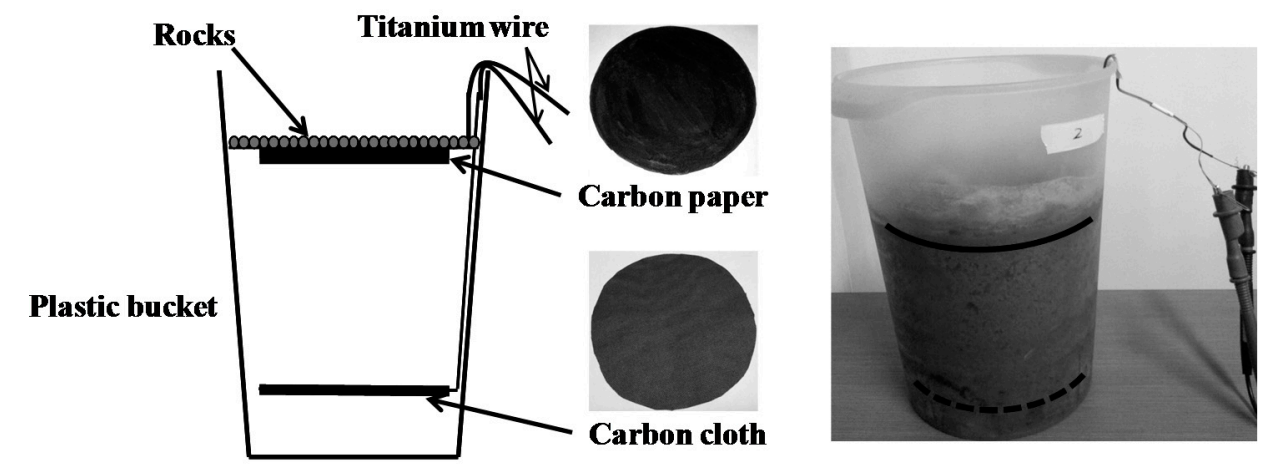

Figure 9. Proposed TMFC architecture.

\subsection{Performance Evaluation of the TMFC}

\subsubsection{Electrochemical Tests}

The TMFC reactor is inoculated and works at room temperature (about $25^{\circ} \mathrm{C}$ ). In the inoculation experiments, an external $1-\mathrm{k} \Omega$ resistor is connected to the anode and cathode. In the beginning, the original soil (with a moisture content of about $0.15 \mathrm{~g} / \mathrm{g}$ by weight) is used in the experiments. The output voltage of TMFC remained zero for more than seven days. Then, $1 \mathrm{~L}$ of DI water-based medium (with $500 \mathrm{mg}$ glucose and $500 \mathrm{mg} \mathrm{NaCl}$ ) was added to the TMFC reactor. Glucose is helpful in enhancing the nutrients of the soil, and $\mathrm{NaCl}$ is helpful in increasing the level of ions in the setup. Glucose and $\mathrm{NaCl}$ are not indispensable here. They are used to reduce the inoculation time. A rapid voltage (current) increase is observed, and the voltage then remains stable a few days later. This suggests that the inoculation process has been realized $[1,11,19]$.

The voltage between anode and cathode was recorded using a digital multimeter (VC86E, VICTOR, Shenzhen, China). When the inoculation experiments were completed, the external 1-k $\Omega$ resistor was 
disconnected, and the OCV was measured using the digital multimeter. After the OCV reached the stable values, the polarization curve was produced as follows: A series of resistors were connected to the TMFC output with the resistance progressively changed from $10 \mathrm{k} \Omega$ to $50 \Omega$ every $10 \mathrm{~min}$. Ten minutes were sufficient for the TMFC reactor to reach the steady state after each resistance change [35]. The values of the output voltage and resistance of the resistors were recorded every time. The associated current was also calculated (by dividing the recorded voltage by the external resistance).

\subsubsection{Environmental Factors Effects on the Performance of TMFC}

In order to improve the power generation performance of the proposed TMFC, the impact of the environmental factors (temperature and soil moisture content by weight) was analyzed. The environmental temperature was about $25{ }^{\circ} \mathrm{C}$. The soil moisture content was recorded using a soil moisture tester (TZS-I, Top Instrument, Hangzhou, China). At first, soil with low water content was selected. The water content was increased by adding DI water into the reactor; this is more convenient than using an oven drying method. We waited about $1 \mathrm{~h}$ every time for the TMFC to reach a stable state. It is validated that this method has a lesser effect on the microorganism in the soil than oven drying technique.

The reactor was placed in a temperature humidity chamber (THS-B4H-100, KSON, New Taipei, Taiwan) to test the relationship between temperature and power density. The temperature was progressively changed from -6 to $42{ }^{\circ} \mathrm{C}$ with an interval of $3{ }^{\circ} \mathrm{C}$. The soil moisture content was kept at about $0.4 \mathrm{~g} / \mathrm{g}$ during the experiments. It indicated that maintaining at least one hour at every temperature is enough to produce the polarization curves.

\subsection{WSN Platform Implementation}

The WSN platform comprises two parts: a sensor node and an access point. The sensor node consists of two sensors, a signal processing board, a controller and radio board, a TMFC reactor, and a PMS board. The access point includes a controller and a radio board (the same as used in the sensor node), a PC, an interface, and a Joint Test Action Group (JTAG) board. The overall block diagram of the WSN platform is shown in Figure 10.

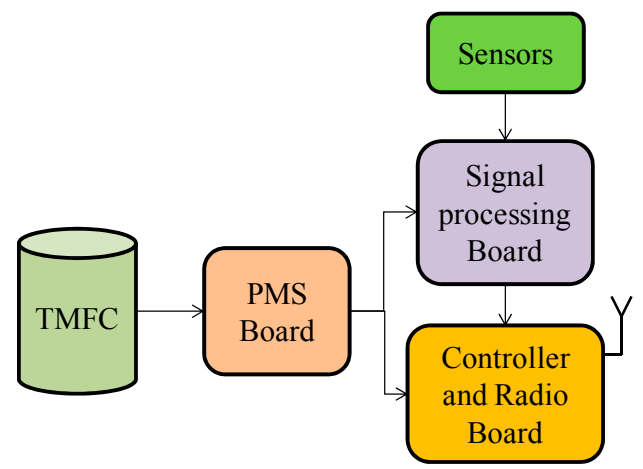

Sensor Node

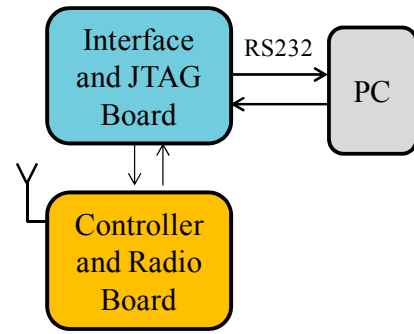

Access Point

Figure 10. Overall block diagram of the Wireless Sensor Network (WSN) platform. JTAG, Joint Test Action Group.

\subsubsection{Sensors and Signal Processing Board}

Two sensors are selected for environmental monitoring. One is for temperature monitoring (WZP-010, Heraeus, Hanau, Germany), and the other is for atmospheric pressure monitoring (MPS30H0500AT, MEMStek, Wuxi, China). Because the output signals coming from the sensors are very weak and are easily affected by noise, a sensor signal processing board is designed to amplify the output signals of sensors. After amplifications, the signals are acquired by the controller. The main 
component of the signal processing board is a precision amplifier (OPA2340, TI, Dallas, TX, USA). It can operate at a voltage as low as $2.5 \mathrm{~V}$. The schematic diagram of the signal processing board is shown in Figure 11.

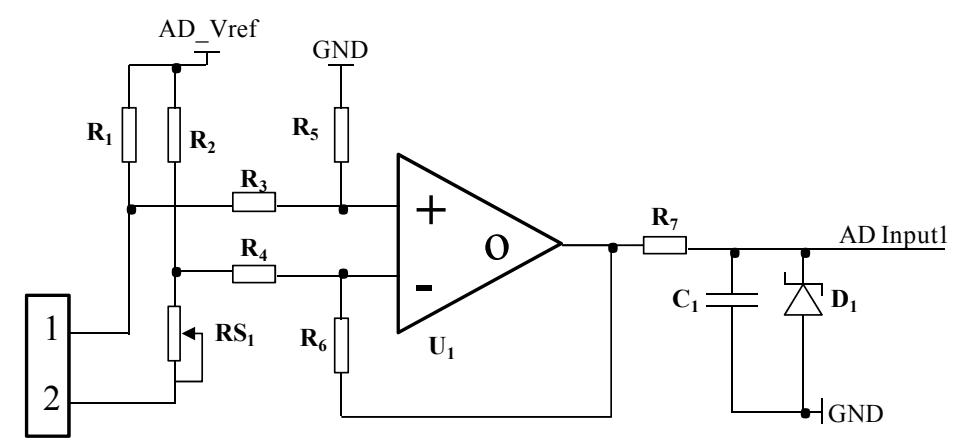

Output of

temperature sensor

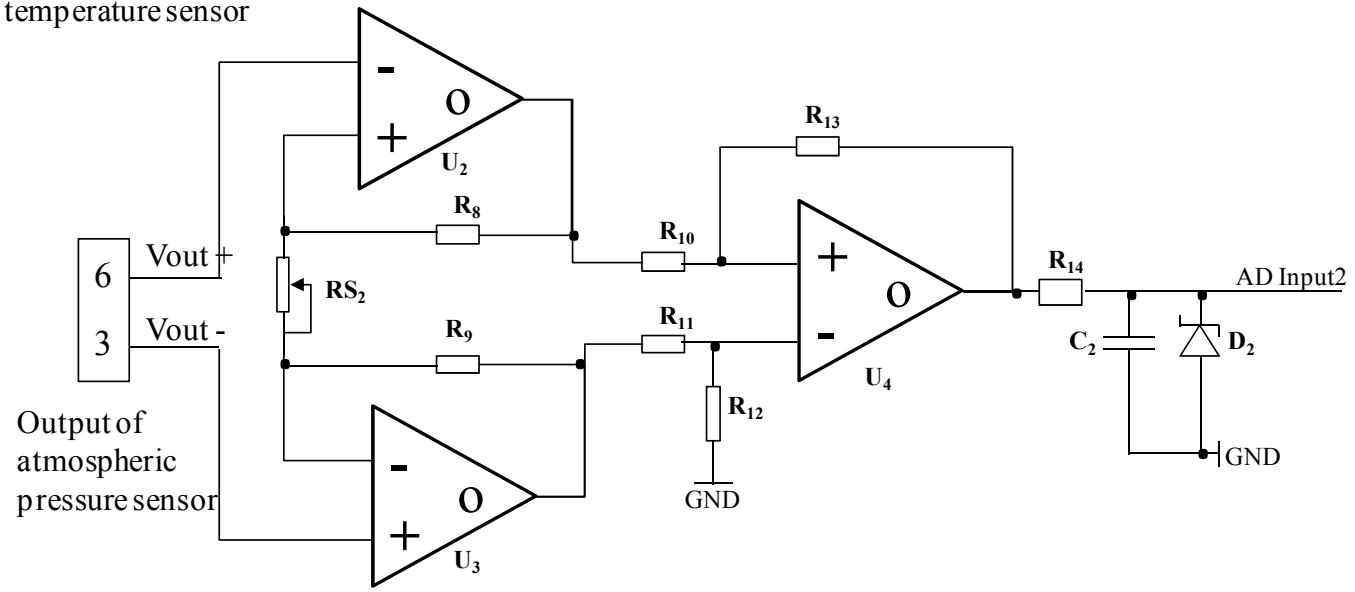

Figure 11. Schematic diagram of the signal processing board. GND, Ground.

The Net label AD_Vref is connected to the AD convertor's reference voltage pin of the controller chip. $\mathrm{AD}$ Input1 and $\mathrm{AD}$ Input2 are connected to the $\mathrm{AD}$ convertor's input 0 pin and input1 pin of the controller chip, respectively. The adjustable resistor $\mathrm{RS}_{1}$ is used to adjust the output voltage of $U_{1}$. The adjustable resistor $R S_{2}$ is used to adjust the output voltage of $U_{2}$ and $U_{3}$, and then can adjust the output voltage of $\mathrm{U}_{4}$. The Zener diodes $\mathrm{D}_{1}$ and $\mathrm{D}_{2}$ are used to protect the $\mathrm{AD}$ convertor of the controller chip from overvoltage. The values of the parameters of the components shown in the diagram are reported in Table 1.

Table 1. Values of the component parameters shown in Figure 11.

\begin{tabular}{ccc}
\hline Name & Symbol & Value/Name of the Component \\
\hline \multirow{3}{*}{ Variable Resistor } & $\mathrm{RS}_{1}, \mathrm{RS}_{2}$ & $500 \Omega$ \\
& $\mathrm{R}_{1}, \mathrm{R}_{2}$ & $500 \Omega$ \\
& $\mathrm{R}_{3}, \mathrm{R}_{4}$ & $25 \mathrm{~K} \Omega$ \\
\hline \multirow{2}{*}{ Resistor } & $\mathrm{R}_{5}, \mathrm{R}_{6}, \mathrm{R}_{8}, \mathrm{R}_{9}$ & $100 \mathrm{~K} \Omega$ \\
& $\mathrm{R}_{7}, \mathrm{R}_{14}$ & $1 \mathrm{~K} \Omega$ \\
& $\mathrm{R}_{10}, \mathrm{R}_{11}, \mathrm{R}_{12}, \mathrm{R}_{13}$ & $10 \mathrm{~K} \Omega$ \\
\hline Capacitor & $\mathrm{C}_{1}, \mathrm{C}_{2}$ & $10 \mathrm{nF}$ \\
\hline Zener Diode & $\mathrm{D}_{1}, \mathrm{D}_{2}$ & $\mathrm{IN} 4733$ \\
\hline Amplifier & $\mathrm{U}_{1}, \mathrm{U}_{2}, \mathrm{U}_{3}, \mathrm{U}_{4}$ & $\mathrm{OPA} 2340$
\end{tabular}




\subsubsection{Controller and Radio Board}

The controller and radio board were designed for data conversion, processing, and wireless transmission. A true system-on-chip solution for 2.4-GHz IEEE 802.15.4 and ZigBee application chip (CC2530F256, TI, Dallas, TX, USA) has been adopted. It includes a 2.4 GHz IEEE 802.15.4 compliant Radio Frequency (RF) transceiver, a high-performance and low-power 8051 microcontroller with code prefetch, and a 12-Bit ADC with eight channels. Thus, sensor data acquisition, processing, and wireless transmission can be realized on a single chip, which simplifies the circuit and reduces power consumption. The power consumption is about $90 \mathrm{~mW}$, while sending data under $1 \mathrm{dBm}$. It also has two powerful USARTs with support for several serial protocols, which is convenient for the board to communicate with a PC. The overall diagram of the board is shown in Figure 12.

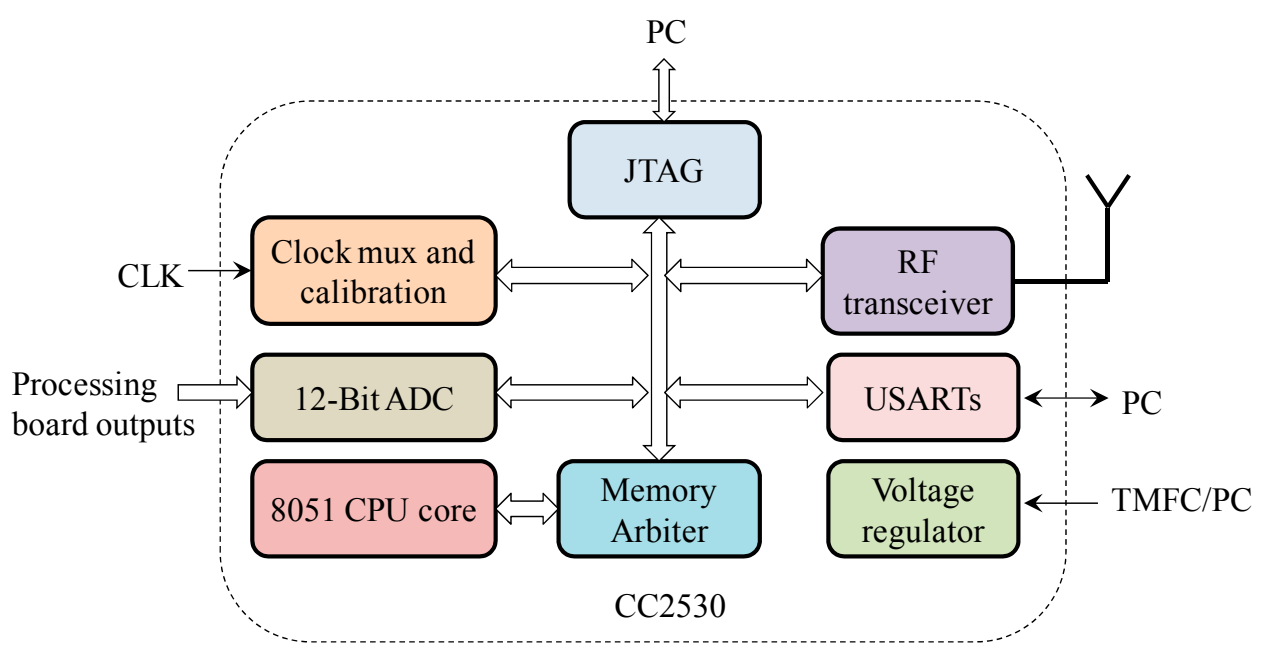

Figure 12. Overall diagram of the controller and the radio board. RF, Radio Frequency. CLK, Clock.

The controller and radio boards in sensor node and access point have the same structure. However, the controller and radio board at the sensor node is powered by the TMFC reactor through the PMS board, and the controller and radio board in the access point is powered by the PC via USB.

\subsubsection{PMS Board}

Because of the low output voltage and low output power density of TMFCs, it requires a PMS to connect a TMFC to the electronic load. A capacitor-transformer converter PMS board is designed based on our previous study [19]. The principle diagram of the PMS board is shown in Figure 13.

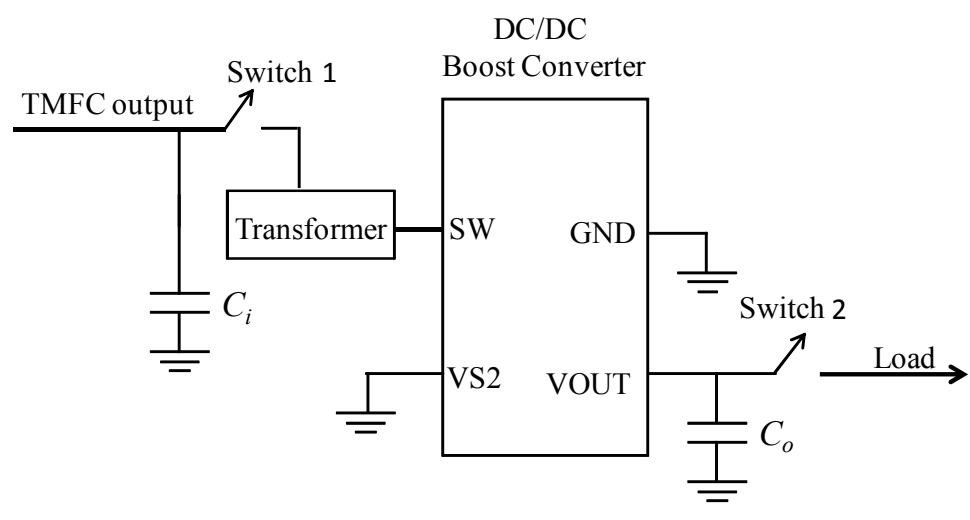

Figure 13. Principle diagram of the PMS board. 
Two super-capacitors are used in the PMS circuit: One is directly connected to the TMFC output electrodes, and the other is connected to the DC/DC converter output pins. The first super-capacitor $\left(C_{i}\right)$ is used for accumulating power from the TMFC and driving the following DC/DC converter. This super-capacitor needs to be optimized. The optimal value of the first super-capacitor is $1 \mathrm{~F}$ based on the method of our previous study $[19,24]$. The second super-capacitor $\left(C_{0}\right)$ is used for storing energy from the DC/DC converter and drives the electronic load. Its capacitance is determined based on the power consumption of the load. The value is $100 \mathrm{mF}$ based on the experimental results of transmitting three packets in one duty cycle. In this application, LT3108 (Linear Technology, Milpitas, CA, USA) is selected as the DC/DC converter. When the voltage of the first super-capacitor $C_{i}$ reaches the turn-on voltage of Switch 1, Switch 1 closes. The first super-capacitor powers the rest of the PMS and the load as a power source. Similarly, when the voltage of the second super-capacitor $C_{0}$ achieves the turn-on voltage of Switch 2, Switch 2 closes and the energy storing in the super-capacitor $C_{0}$ starts to drive the load. The minimum acceptable input voltage of the board is $0.18 \mathrm{~V}$, and the maximum output voltage is $3.3 \mathrm{~V}$.

Acknowledgments: The authors would like to thank the supports by the National Natural Science Foundation of China (No. 61201021, No. 51306134) and the Province Natural Science Foundation of Shaanxi (No. 2015JM6335).

Author Contributions: Daxing Zhang and Yongxian Guo conceived, designed, and performed the experiments; Daxing Zhang and Yingmin Zhu analyzed the data; Witold Pedrycz reviewed and modified the paper; Daxing Zhang wrote the paper.

Conflicts of Interest: The authors declare no conflict of interest.

$\begin{array}{ll}\text { Abbreviations } \\ \text { MFCs } & \text { Microbial Fuel Cells } \\ \text { TMFCs } & \text { Terrestrial Microbial Fuel Cells } \\ \text { AMFCs } & \text { Aquatic Microbial Fuel Cells } \\ \text { WSNs } & \text { Wireless Sensor Networks } \\ \text { BESs } & \text { Bioelectrochemical Systems } \\ \text { OCV } & \text { Open Circuit Voltage } \\ \text { PMS } & \text { Power Management System } \\ \text { PC } & \text { Personal Computer } \\ \text { USB } & \text { Universal Serial Bus } \\ \text { JTAG } & \text { Joint Test Action Group } \\ \text { USART } & \text { Universal Synchronous Asynchronous Receiver Transmitter } \\ \text { RF } & \text { Radio Frequency } \\ \text { ADC } & \text { Analog to Digital Converter } \\ \text { DC/DC } & \text { Direct Current to Direct Current }\end{array}$

\section{References}

1. Logan, B.E. Microbial Fuel Cells, 1st ed.; John Wiley \& Sons Inc.: New York, NY, USA, 2008; pp. 1-11.

2. Rabaey, K. Bioelectrochemical Systems: From Extracellular Electron Transfer to Biotechnological Application; IWA Publishing: London, UK, 2010; pp. 1-10.

3. Sleutels, T.H.; Ter Heijne, A.; Buisman, C.J.; Hamelers, H.V. Bioelectrochemical systems: An outlook for practical applications. ChemSusChem 2012, 5, 1012-1019. [CrossRef] [PubMed]

4. Kannan, M.V.; Gnana Kumar, G. Current status, key challenges and its solutions in the design and development of graphene based ORR catalysts for the microbial fuel cell applications. Biosens. Bioelectron. 2016, 77, 1208-1220. [CrossRef] [PubMed]

5. $\quad$ Majumder, D.; Maity, J.P.; Tseng, M.J.; Nimje, V.R.; Chen, H.R.; Chen, C.C.; Chang, Y.F.; Yang, T.C.; Chen, C.Y. Electricity generation and wastewater treatment of oil refinery in microbial fuel cells using Pseudomonas putida. Int. J. Mol. Sci. 2014, 15, 16772-16786. [CrossRef] [PubMed]

6. Shizas, I.; Bagley, D.M. Experimental determination of energy content of unknown organics in municipal wastewater streams. J. Energy Eng. 2004, 130, 45-53. [CrossRef] 
7. Potter, M.C. Electrical Effects Accompanying the Decomposition of Organic Compounds. In Proceedings of the Royal Society of London, Series B, Containing Papers of a Biological Character, London, UK, 14 September 1911; Royal Society: London, UK, 1911; pp. 260-276.

8. Schröder, U. Discover the possibilities: Microbial bioelectrochemical systems and the revival of a 100-year-old discovery. J. Solid State Electron. 2011, 15, 1481-1486. [CrossRef]

9. Logan, B.E. Essential data and techniques for conducting microbial fuel cell and other types of bioelectrochemical system experiments. ChemSusChem 2012, 5, 988-994. [CrossRef] [PubMed]

10. Ghadge, A.N.; Jadhav, D.A.; Pradhan, H.; Ghangrekar, M.M. Enhancing waste activated sludge digestion and power production using hypochlorite as catholyte in clayware microbial fuel cell. Bioresour. Technol. 2015, 182, 225-231. [CrossRef] [PubMed]

11. Wang, H.M.; Park, J.D.; Ren, Z.J. Practical energy harvesting for microbial fuel cells: A review. Environ. Sci. Technol. 2015, 49, 3267-3277. [CrossRef] [PubMed]

12. Fang, F.; Zang, G.L.; Sun, M.; Yu, H.Q. Optimizing multi-variables of microbial fuel cell for electricity generation with an integrated modeling and experimental approach. Appl. Energy 2013, 110, 98-103. [CrossRef]

13. Rajesh, P.P.; Jadhav, D.A.; Ghangrekar, M.M. Improving performance of microbial fuel cell while controlling methanogenesis by Chaetoceros pretreatment of anodic inoculum. Bioresour. Technol. 2015, 180, 66-71. [CrossRef] [PubMed]

14. Park, J.D.; Ren, Z.Y. Hysteresis-Controller-based energy harvesting scheme for microbial fuel cells with parallel operation capability. IEEE Trans. Energy Convers. 2012, 27, 715-724. [CrossRef]

15. Janicek, A.; Fan, Y.Z.; Liu, H. Performance and stability of different cathode base materials for use in microbial fuel cells. J. Power Sources 2015, 280, 159-165. [CrossRef]

16. Selvan, K.V.; Ali, M.S.M. Micro-scale energy harvesting devices: Review of methodological performances in the last decade. Renew. Sustain. Energy Rev. 2016, 54, 1035-1047. [CrossRef]

17. Santoro, C.; Soavi, F.; Serov, A.; Arbizzani, C.; Atanassov, P. Self-powered supercapacitive microbial fuel cell: The ultimate way of boosting and harvesting power. Biosens. Bioelectron. 2016, 78, 229-235. [CrossRef] [PubMed]

18. Pandey, P.; Shinde, V.N.; Deopurkar, R.L.; Kale, S.P.; Patil, S.A.; Pant, D. Recent advances in the use of different substrates in microbial fuel cells toward wastewater treatment and simultaneous energy recovery. Appl. Energy 2016, 168, 706-723. [CrossRef]

19. Yang, F.; Zhang, D.X.; Shimotori, T.; Wang, K.C.; Huang, Y. Study of transformer-based power management system and its performance optimization for microbial fuel cells. J. Power Sources 2012, 205, 86-92. [CrossRef]

20. Del Campo, A.G.; Lobato, J.; Canizares, P.; Rodrigo, M.A.; Morales, F.J.F. Short-term effects of temperature and COD in a microbial fuel cell. Appl. Energy 2013, 101, 213-217. [CrossRef]

21. Dallago, E.; Barnabei, A.L.; Liberale, A.; Torelli, G.; Venchi, G. A 300-mV low-power management system for energy harvesting applications. IEEE Trans. Power Electron. 2016, 31, 2273-2281. [CrossRef]

22. Khaled, F.; Ondel, O.; Allard, B. Microbial fuel cells as power supply of a low-power temperature sensor. J. Power Sources 2016, 306, 354-360. [CrossRef]

23. Dewan, A.; Ay, S.U.; Karim, M.N.; Beyenal, H. Alternative power sources for remote sensors: A review. J. Power Sources 2014, 245, 129-143. [CrossRef]

24. Thomas, Y.R.J.; Picot, M.; Carer, A.; Berder, O.; Sentieys, O.; Barrière, F. A single sediment-microbial fuel cell powering a wireless telecommunication system. J. Power Sources 2013, 241, 703-708. [CrossRef]

25. Zhang, D.X.; Yang, F.; Shimotori, T.; Wang, K.C.; Huang, Y. Performance evaluation of power management systems in microbial fuel cell-based energy harvesting applications for driving small electronic devices. J. Power Sources 2012, 217, 65-71. [CrossRef]

26. Han, Y.; Yu, C.; Liu, H. A microbial fuel cell as power supply for implantable medical devices. Biosens. Bioelectron. 2010, 25, 2156-2160. [CrossRef] [PubMed]

27. Tommasi, T.; Chiolerio, A.; Crepaldi, M.; Demarchi, D. A microbial fuel cell powering an all-digital piezoresistive wireless sensor system. Microsyst. Technol. 2014, 20, 1023-1033. [CrossRef]

28. Carreon-Bautista, S.; Erbay, C.; Han, A.; Sanchez-Sinencio, E. Power management system with integrated maximum power extraction algorithm for microbial fuel cells. IEEE Trans. Energy Convers. 2015, 30, $262-272$. [CrossRef] 
29. Meehan, A.; Gao, H.W.; Lewandowski, Z. Energy harvesting with microbial fuel cell and power management system. IEEE Trans. Power Electron. 2011, 26, 176-181. [CrossRef]

30. Bandyopadhyay, P.R.; Thivierge, D.P.; McNeilly, F.M.; Fredette, A. An electronic circuit for trickle charge harvesting from littoral microbial fuel cells. IEEE J. Ocean. Eng. 2013, 38, 32-42. [CrossRef]

31. Zhang, F.; Tian, L.; He, Z. Powering a wireless temperature sensor using sediment microbial fuel cells with vertical arrangement of electrodes. J. Power Sources 2011, 196, 9568-9573. [CrossRef]

32. Knight, C.; Cavanagh, K.; Munnings, C.; Moore, T.; Cheng, K.Y.; Kaksonen, A.H. Application of microbial fuel cells to power sensor networks for ecological monitoring. In Wireless Sensor Networks and Ecological Monitoring; Springer: Berlin/Heidelberg, Germany, 2013; Volume 3, pp. 151-178.

33. Zheng, Q.; Xiong, L.; Mo, B.; Lu, W.; Kim, S.; Wang, Z. Temperature and humidity sensor powered by an individual microbial fuel cell in a power management system. Sensors 2015, 15, 23126-23144. [CrossRef] [PubMed]

34. Cooke, K.G.; Gay, M.O.; Radachowsky, S.E.; Guzman, J.J.; Chiu, M.A. BackyardNet(TM): Distributed sensor network powered by terrestrial microbial fuel cell technology. In Proceedings of the SPIE Defense, Security, and Sensing, Orlando, FL, USA, 12 May 2010; International Society for Optics and Photonics: Orlando, FL, USA, 2010; pp. 1-11.

35. Zhang, D.X.; Ge, Y.B.; Wang, W.D. Study of a terrestrial microbial fuel cell and the effects of its power generation performance by environmental factors. In Proceedings of the 2013 IEEE International Conference on Advanced Mechatronic Systems (ICAMechS), Luoyang, China, 25-27 September 2013; pp. 445-448.

36. Pietrelli, A.; Micangeli, A.; Ferrara, V.; Raffi, A. Wireless sensor network powered by a terrestrial microbial fuel cell as a sustainable land monitoring energy system. Sustainability 2014, 6, 7263-7275. [CrossRef]

37. Dargie, W.; Poellabauer, C. Fundamentals of Wireless Sensor Networks: Theory and Practice; John Wiley \& Sons: New York, NY, USA, 2010; pp. 9-13.

38. Seah, W.K.; Eu, Z.A.; Tan, H.P. Wireless sensor networks powered by ambient energy harvesting (WSN-HEAP)-Survey and challenges. In Proceedings of the 1st International Conference on Wireless Communication, Vehicular Technology, Information Theory and Aerospace \& Electronic Systems Technology, Wireless VITAE 2009, Aalborg, Denmark, 17-20 May 2009; IEEE: Aalborg, Denmark, 2009; pp. 1-5.

39. Peng, S.; Low, C.P. Prediction free energy neutral power management for energy harvesting wireless sensor nodes. Ad Hoc Netw. 2014, 13, 351-367. [CrossRef]

40. Escolar, S.; Chessa, S.; Carretero, J. Energy-neutral networked wireless sensors. Simul. Model. Pract. Theory 2014, 43, 1-15. [CrossRef]

(C) 2016 by the authors; licensee MDPI, Basel, Switzerland. This article is an open access article distributed under the terms and conditions of the Creative Commons Attribution (CC-BY) license (http:/ / creativecommons.org/licenses/by/4.0/). 